\title{
COMPARISON OF EMPIRICAL PET ESTIMATION METHODS IN THE YELLOW RIVER BASIN
}

\author{
Weihua FANG ${ }^{1,2}$ and Hidefumi IMURA ${ }^{3}$ \\ ${ }^{1}$ Doctoral Student, Division of Environmental Engineering and Architecture, Graduate School of Environmental \\ Studies, Nagoya University \\ (Furo-cho, Chikusa-ku, Nagoya, 464-8603, Japan) \\ E-mail: s010213d@mbox.nagoya-u.ac.jp \\ 2 Doctoral Student, Institute of Natural Resources Sciences, Beijing Normal University \\ (Beijing Normal University, Xingjiekouwai Street., Beijing, 100875, China) \\ E-mail: fang@bnu.edu.cn \\ ${ }^{3}$ Member of JSCE, Professor, Division of Environmental Engineering and Architecture, Graduate School of \\ Environmental Studies, Nagoya University \\ (Furo-cho, Chikusa-ku, Nagoya, 464-8603, Japan) \\ E-mail: imura@genv.nagoya-u.ac.jp
}

\begin{abstract}
This study presents the estimation of potential evapotranspiration (PET) in the Yellow River basin. The applicability and meteorological parameter availability are the main factors influencing PET estimation. Firstly, it compares and calibrates six empirical PET methods with Penman-Monteith method as standard criteria. The six empirical methods are Thornthwaite, Blaney-Criddle, Hargreaves, Priestley-Taylor, Makkink and Penman methods. A complete daily meteorological record of 10 stations in the year of 2002 is used for comparison and calibration. Secondly, the PET in the Yellow River basin is estimated by the calibrated Makkink method with temperature and sunshine duration hours from 190 stations.
\end{abstract}

Key Words : the Yellow River basin, potential evapotranspiration, empirical method, calibration

\section{INTRODUCTION}

The Yellow River basin had witnessed severe water resources shortage and has becoming a hotspot area from the water resources study point of view during the past several decades. The dryup days increased from 19 days in the year of 1972 to 226 days in $1997^{1)}$. Past studies shows the general trend of precipitation kept decreasing and the runoff kept decreasing $^{2}$. In the meaning time, the general trend of and evapotranspiration $(E T)$ continued increasing in the Yellow River basin during this period ${ }^{3)}$. Future PET changes under the background of global changes will impose dramatic impact to the spatial and temporal distribution of water resources in the Yellow River basin.

Classical empirical PET models could be widely used when aiming at future water resources problems, both in Regional Climate Models ( $R C M s)$ and many application fields. In the study of ET, Potential evapotranspiration $(P E T)$ is proposed as the amount of water that could be evaporated from land, water, and plant surfaces if soil water were in unlimited supply4) and has become a major index to reflect evapotranspiration ability under different local climate and land surface conditions. A variety of empirical methods, such as Penman-Monteith, Thornthwaite, Blaney-Criddle, Hargreaves, Priestley-Taylor, Makkink and Penman methods, have been developed for estimating PET in the past studies. Moreover, recent development of remote sensing, provides a range of sensors with the ability of estimating surface parameters and hence PET. Remote sensing is valuable in the sense of information sources, especially in large scale heterogeneous areas ${ }^{5)}$. At the same time, classical empirical PET models will still play an important role in the modeling of future water resources problems. Firstly, classical empirical equations for estimating PET are often widely utilized in Regional Climate Models not only for reconstructing past climate situations, but more importantly, for the 
modeling future climate change scenarios under global climate change. In order to integrate the impact of global climate change into regional water resources modeling, results of General Circulation Models $(G C M s)$ are often used as boundary conditions for RCMs and different RCMs might demand totally different input climate parameters and hence different empirical PET equations ${ }^{6)}$. Secondly, classical empirical PET equations are also widely used in a variety of application fields. For instance, estimation of future crop irrigation water demand would be heavily relied on the estimation of future evapotranspirtation ${ }^{4)}$.

The generalization and data availability are often the two major factors influencing PET estimating application because most empirical methods were originally developed based on past local climate conditions. Firstly, due to the inherent limitation of empirical equations and the complicate mechanism of ET process, the generalization of empirical ET methods must be checked and calibrated before being applied to local areas. Secondly, the data requirements for computing PET by different methods vary a lot, from only location and monthly mean temperature by Thornthwaite method, to ten meteorological parameters by Penman-Monteith method. When applying these empirical evapotranspiration models to RCMs, it is advisable to compare the applicability and data requirement according to local climate conditions and dataset availability. Some past local comparison studies shows that different empirical estimation methods might produce different PET results ${ }^{7,8)}$. In the case of the Yellow River basin, few comparison studies have been done with emphasise on comparing the applicability of empirical PET equations.

The objective of this study is to compare and calibrate six empirical methods with Penman-Monteith method as standard criteria and then estimate PET in the Yellow River basin as a example. Penman-Monteith method was selected as a proxy to substitute actual PET due to the lack of sufficient actual mornitoring PET data. The six empirical methods chosen in this study are Thornthwaite, Blaney-Criddle, Hargreaves, Priestley-Taylor, Makkink and Penman methods. The data for calibrating empirical PET methods is a daily record of ten meteorological parameters in 10 stations in the Yellow River basin in 2002. After comparison and calibration, Makkink method is selected to estimate the average PET in the Yellow River basin, with 10-day mean temperature and sunshine duration of 190 stations covering the Yellow River domain from the year of 1961 to 1990.

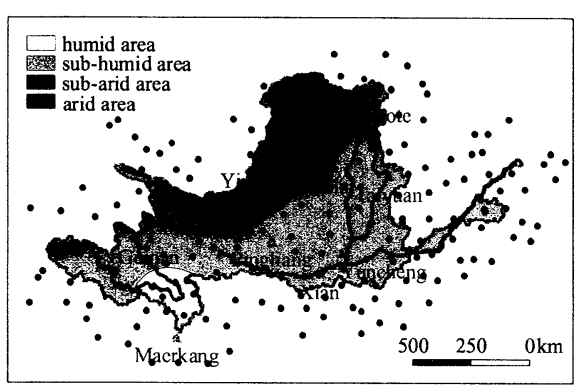

Fig. 1 Meteorological stations in the Yellow River domain.

\section{EMPIRICAL PET METHODS}

The characters of each empirical method are to be discussed in this part. In this study, the practical equations and constants for estimating PET by FAO-56 Penman-Monteith method ${ }^{4)}$ are listed in the appendix. The six empirical methods are discussed in detail one by one. Except for Thornthwaite method, the other five empirical PET methods, together with Penman-Monteith method, are in the form of computing daily ET. The meaning and units of symbols in the six empirical PET methods, if not expressed explicitly, are the same to those of Penman-Monteith method.

\section{(1) Thornthwaite method}

Thornthwaite method is the procedure of monthly calculation with the greatest international acceptance with the merits of requiring only mean monthly temperature data and simple computing process ${ }^{9}$. The limitation is that it can be used for computing monthly evapotranspiration only. The equations for Thornthwaite method is as follows:

$$
\begin{gathered}
E T=1.6\left(\frac{10 T_{a}}{I}\right)^{a} \\
I=\sum\left(\frac{T_{i}}{5}\right)^{1.514} \\
a=\left(492390+17929 I-77.1 I^{2}+0.675 I^{3}\right) \times 10^{-6}
\end{gathered}
$$

where $E T$ are monthly evapotranspiration and $T_{a}$ is mean monthly air temperature.

\section{(2) Blaney-Criddle method}

Blaney-Criddle method requires daily mean temperature only and has been used widely in the following form ${ }^{10)}$ :

$$
E T=k p\left(0.46 T_{a}+8.13\right)
$$

where $k$ is 0.85 and 0.45 for growing season (May to September) and non-growing season respectively. $p$ 
is daily percentage of annual daytime hours. With $k$ as an empirical coefficient, this method provides the flexibility to fit local situation.

\section{(3) Hargreaves method}

After several improvements, Hargreaves proposed the following equation for calculating ET in $1985^{11)}$,

$$
E T=a R_{a} T D^{1 / 2}\left(T_{a}+17.8\right)
$$

where $a$ is constant 0.0023 , and TD is the difference between daily maximum and minimum temperature. Different from Blaney-Criddle method, Hargreaves method integrates extraterrestrial radiation $R_{a}$ into estimation process. Since $R_{a}$ is merely related to location information, the data requirements for this method are daily maximum and minimum temperatures only.

\section{(4) Makkink method}

Makkink method for estimating PET is as follows $^{12)}$,

$$
E T=0.61 \frac{\Delta}{\Delta+\gamma} \frac{R_{s}}{\lambda}-0.12
$$

This method needs daily mean temperature, air pressure, and sunshine duration hours. For the simplicity of computation in this study, the angstrom coefficients $a_{s}$ and $b_{s}$ for computing solar radiation $R_{s}$ are the same to Penman-Monteith method (equation 9 in the appendix). The units of Makkink method for computing daily ET are cal $\mathrm{cm}^{-2} d a y^{-1}$ for $R_{s}$ and $m b{ }^{\rho} C$ for $\Delta, \gamma$ and $\lambda$, which are different from Penman-Monteith method.

\section{(5) Priestley-Taylor method}

Priestley and Taylor proposed a simplified version of the combination equation in 1972 in the condition of wet surface areas ${ }^{13}$. The aerodynamic component was not considered and the energy component was replaced by coefficient $\alpha$ with the value of 1.26 .

$$
E T=\alpha \frac{\Delta}{\Delta+\gamma} \frac{R_{n}}{\lambda}
$$

Different from Makkink method, Priestley-Taylor method requires more meteorological parameters, which are daily maximum temperature, minimum temperature, relative humidity, air pressure and sunshine duration hours.

\section{(6) Penman method}

Penman method assumes that ET is controlled by wind speed and vapour pressure difference between the earth and the atmosphere ${ }^{14)}$. It is primarily for
Table 1 Comparison of PET methods

\begin{tabular}{|lll|}
\hline \multicolumn{1}{|c|}{ Method } & \multicolumn{1}{c|}{ Type } & \multicolumn{1}{c|}{ Data requirement } \\
\hline Thornthwaite & temperature & $T_{a}$ \\
Blaney-Criddle & temperature & $\varphi, z, T_{\max } T_{\min }$ \\
Hargreaves & temperature & $\varphi, z, T_{\max }, T_{\min }$ \\
Makkink & radiation & $\varphi, z, T_{a,} p, n$ \\
Priestley-Taylor & radiation & $\varphi, z, T_{\max }, T_{\min } R H, p, n$ \\
Penman & mass transfer & $\varphi, z, T_{\max }, T_{\min } R H, u_{2}$ \\
Penman-Monteith combination & $\varphi_{s} z, T_{\max } T_{\min } R H, u_{2}, p, n, T_{s}$ \\
\hline
\end{tabular}

free water surface evaporation estimation but also applied to be a proxy estimate PET for its simplicity of form.

$$
E=0.35\left(1+0.0098 u_{2}\right)\left(e_{s}-e_{a}\right)
$$

The units of this method are $m m d^{1}$ for $E, m m H g$ for $e_{s}$ and $e_{a}$ and miles day $y^{-1}$ for $u_{2}$.

\section{(7) Comparison of six empirical methods}

In the practical computation process of this study, there are altogether ten parameters used: latitude $(\varphi)$, elevation $(z)$, maximum temperature $\left(T_{\max }\right)$, minimum temperature $\left(T_{\text {min }}\right)$, mean temperature $\left(T_{a}\right)$, relative humidity $(R H)$, wind speed in the height of 2 meters $\left(u_{2}\right)$, air pressure $(p)$, sunshine duration hours $(n)$ and soil temperature $\left(T_{s}\right)$ in depth of $15 \mathrm{~cm}$ under soil surface. Parameter requirements for each method are listed in Table 1. Penman-Monteith method is a combination method. Thornthwaite method, Blaney-Criddle method and Hargreaves method are temperature-based and require only temperature parameters, besides of latitude and height of station. Makkink method and Priestly-Taylor method consider solar radiation and net radiation respectively and therefore become radiation-based methods. Penman method is primarily for estimating evaporation process and regarded as a mass transfer method.

\section{DATA}

In this study, two datasets are used. The first dataset is for assessing and calibrating the six empirical methods using Penman-Monteith as a standard method. The second dataset is for estimating PET in the Yellow River basin by the calibrated Makkink method.

The first dataset is a complete daily meteorological record of 10 stations (triangles in Fig. 1) in the year of 2002. These stations are spatially equally distributed for representing climate varieties in the Yellow River basin, ranging from arid area (Yinchuan), sub-aid area (Xining, Huhehaote, Yulin), sub-humid area (Guinan, Taiyuan, Pingliang, Yuncheng and Xian), to humid area (Maerkang). 

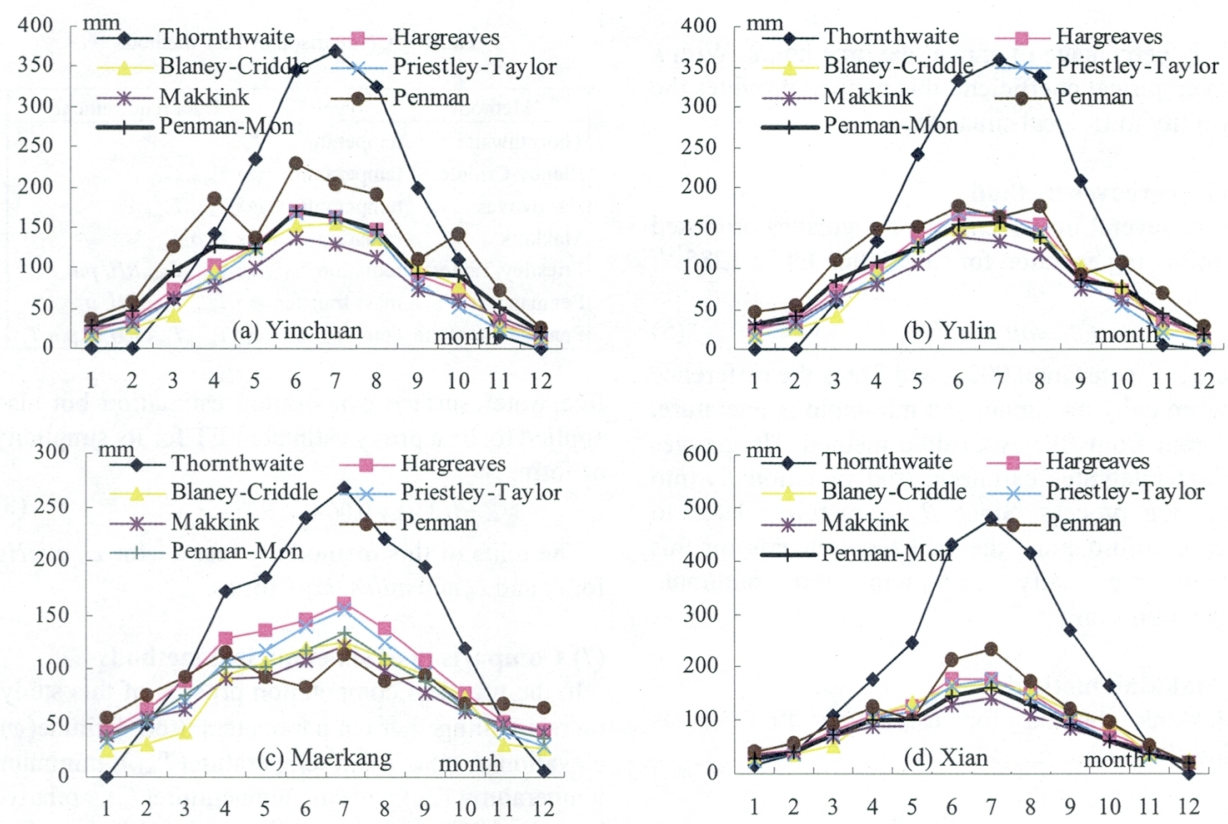

Fig. 2 Monthly PET by empirical and Penman-Monteith methods in 4 climate stations in the Yellow River basin
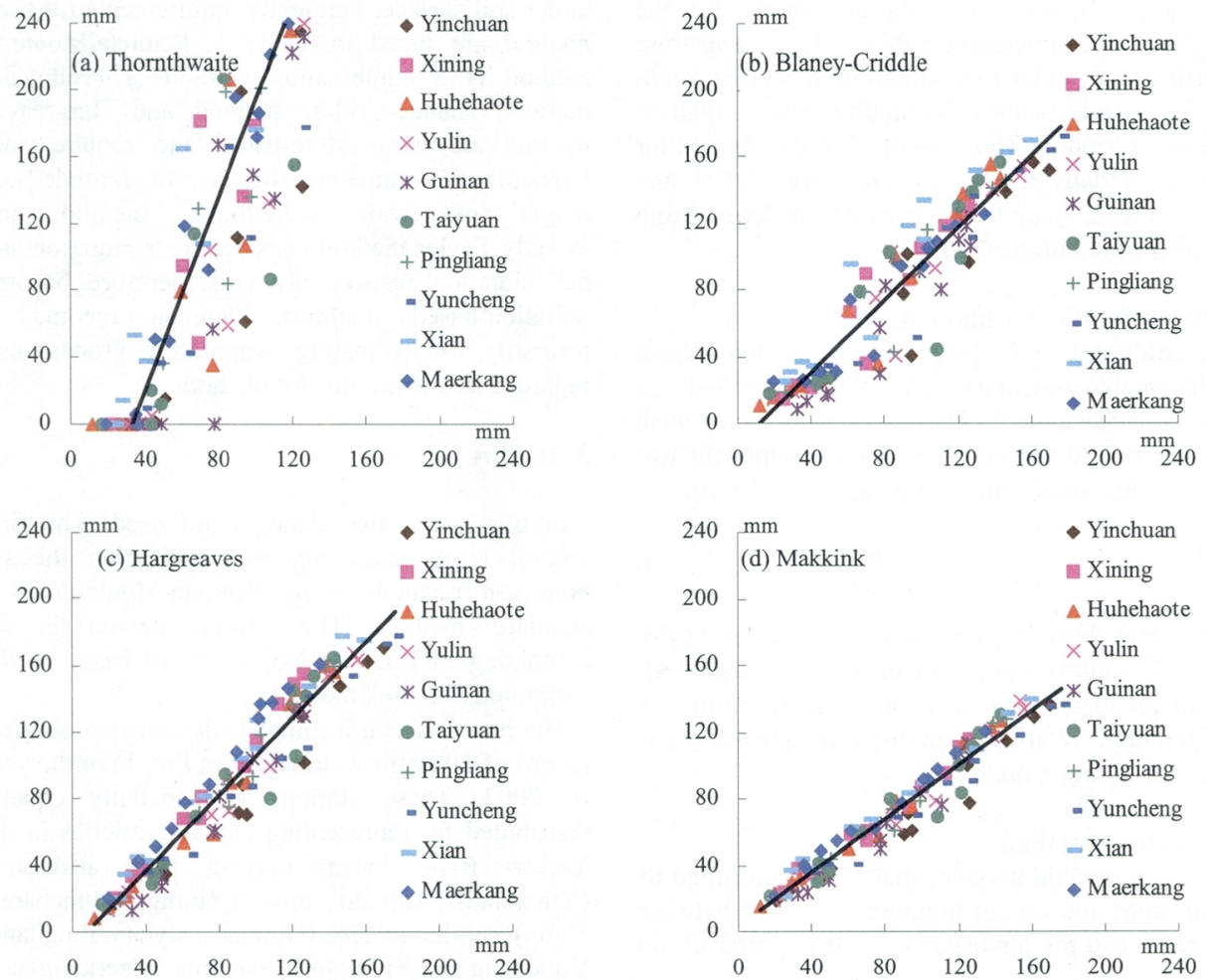

Fig. 3 Calibration of empirical methods (vertical axis) with Penman-Monteith method (horizontal axis) 

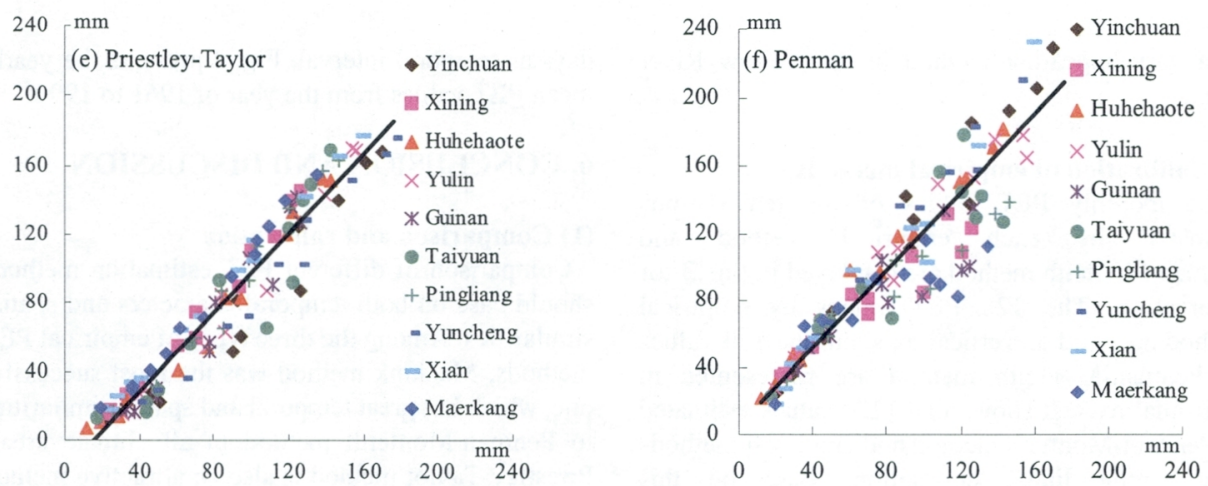

Fig. 3 Calibration of empirical methods (vertical axis) with Penman-Monteith method (horizontal axis)

Table 2 Calibrations of Penman-Monteith (y) and other methods (x)

\begin{tabular}{|lll|}
\hline \multicolumn{1}{|c}{ Method } & \multicolumn{1}{c}{ Calibration Equation } & $R^{2}$ \\
\hline Thornthwaite & $\mathrm{y}=2.89 \mathrm{x}-98.16$ & 0.856 \\
Blaney-Criddle & $\mathrm{y}=1.06 \mathrm{x}-13.6$ & 0.877 \\
Hargreaves & $\mathrm{y}=1.14 \mathrm{x}-9.39$ & 0.938 \\
Priestley-Taylor & $\mathrm{y}=1.16 \mathrm{x}-18.77$ & 0.933 \\
Makkink & $\mathrm{y}=0.81 \mathrm{x}+2.86$ & 0.949 \\
Penman & $\mathrm{y}=1.15 \mathrm{x}+5.67$ & 0.837 \\
\hline
\end{tabular}

Maerkang station is selected as a proxy, which is not inside but in the vicinlity of the humid area in the Yellow River basin, due to the lack of monitoring station in the mountainous area. This dataset covers the ten parameters listed in Table 1 for this study.

The second one is a dataset of 190 stations (dots in Fig. 1) covering whole Yellow River domain with a 10 days temporal interval of 30 years from 1961 to 1990. The only two parameters of this dataset are mean temperature and sunshine duration hours. The stations of this dataset is composed of the stations both inside the Yellow River basin and the $200 \mathrm{~km}$ buffering region starting from basin boundary.

\section{COMPARISON AND CALIBRATION}

\section{(1) Comparison of monthly PET results}

The monthly variation characters of the six empirical methods, together with Penman-Monteith method are compared in this part. Monthly PET values are summarized from daily values for observing seasonal difference, which is critical in many applications such as agriculture irrigation assessment. Yinchuan(Fig.2.a), Yulin(Fig.2.b), Xian(Fig.2.c) and Maerkang(Fig.2.d) are selected as representative stations to reflect regional difference of climate conditions in the arid, sub-area, sub-humid and humid areas in the Yellow River basin. The vertical axis reflects the PET values and the horizontal axis shows different months.

Among the three temperature-based methods,
Thornthwaite method has the poorest performance. Its PET values are overestimated from April to September and underestimated from November to February. Hargreaves method overestimates PET slightly in all climate areas. Blaney-Criddle method achieved relatively good results in arid, sub-arid and sub-humid areas but underestimates PET values in humid area in winter season, though it is primarily proposed for estimating PET under wet surface conditions. Blaney-Criddle method and Hargreaves method can achieve more reasonable results than Thornthwaite method in the Yellow River basin.

The Penman method has large temporal variation in arid areas since it is primarily for computing vapotration over water surface. PET values tend to be overestimated in arid, sub-arid and sub-humid areas and underestimated in humid area in summer.

Both radiation-based methods can provide good results compared to temperature-based methods. Priestley-Taylor method has good performance in almost all the seasons, except for underestimation from December to February in humid area. The temporal characters in all seasons of Makkink method have great similarities to that of Penman-Monteith in all climate areas. It appears to

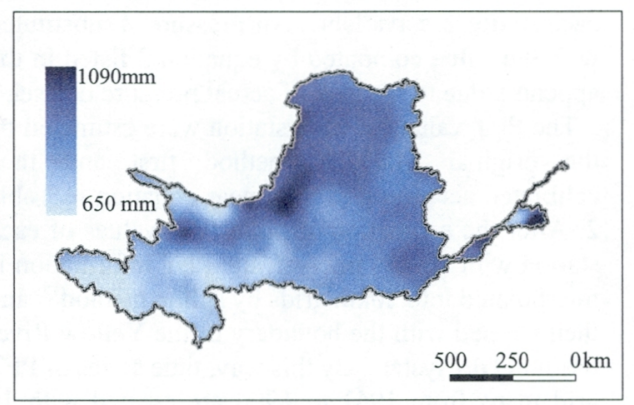

Fig. 4 PET in Yellow River by calibrated Makkink method 
be a very appealing method in the Yellow River basin.

\section{(2) Calibration of empirical methods}

The monthly PET values of the ten stations estimated by each empirical method and Penman-Monteith method are displayed in Fig. 3 for observation. The 120 PET values by empirical method are used as vertical axis and the 120 values by Penman-Monteith method are represented in horizontal axis. It shows that PET values estimated by Penman-Monteith method and empirical methods have strong linear correlation. Base on this understanding, six linear regression equations are developed to reflect the relationship between Penman-Monteith method as variable $\mathrm{x}$ and the other empirical PET methods as variable y (Table 2).

The regression results shows that among the three temperature-based methods, Hargreaves(Fig.3.c) method has the best linear relationship with Penman-Monteith method. As a mass-transfer method, Penman equation(Fig.3.f) has the least distinct relationship with Penman-monteith method. Both radiation-based methods exhibit good results with high $R^{2}$ values. Among the six methods, Makkink(Fig.3.d) achived the best performance with $R^{2}$ value of 0.949 .

\section{PET ESTIMATION IN THE YELLOW RIVER BASIN}

Though the difference of $R_{2}$ values of Makkink, Hargreaves, and Priestley-Taylor are not very large, Makkink shows the best spatial and temporal charactors. Therefore, Makkink method is chosen for estimating PET in the Yellow River basin.

The meteorological records of 30 years from 1961 to 1990 of 190 stations covering the Yellow River domain (dots in Fig. 1) is used for estimating PET in the Yellow River basin. In this dataset, only daily mean temperature and sunshine duration hours, together with the longitude, latitude and elevation of each station are available. Air pressure is substituted with the value computed by equation 3 listed in the appendix due to the lack of actual pressure dataset.

The PET values of each station were estimated by the original Makkink method first and then calibrated according to the linear equation in Table 2. After the estimation of point PET values of each station with 10-day interval, the PET information is interpolated into $20 \mathrm{~km}$ grids by spline method ${ }^{15)}$ and then clipped with the boundary of the Yellow River basin in GIS system. By this way, time series of PET grid maps from 1961 to 1990 are created with 10 days as temporal interval. Fig. 4 presents the yearly mean PET values from the year of 1961 to 1990.

\section{CONCLUSION AND DISCUSSION}

\section{(1) Comparison and calibration}

Comparison of different PET estimation methods should base on both temporal characters and spatial similarities. Among the three types of empirical PET methods, Makkink method was the most successful one, which has great temporal and spatial similarities to Penman-Monteith method in all climate areas. Priestley-Taylor method is also an attractive method except minor underestimation in winter. Among the three temperature-based methods, Blaney-Criddle method and Hargreaves method can achieve more reasonable results than Thornthwaite method. Penman method has large temporal variation in arid areas overestimates PET in most areas. Though the differences of $R_{2}$ values between Hargreaves, Priestley-Taylor and Makkink are not very obvious, Makkink shows better spatial and temporal characters. So Makkink method is chosen for estimating PET in the Yellow River basin.

\section{(2) Better temporal and spatial resolution}

Markkin method and some other empirical methods require far less input climate parameters than Penman-Monteith method and therefore there will be more stations satisfying the parameter requirement.. Temporal characters are critical to some application such as crop irrigation demand estimation. Methods tending to overestimate or underestimate PET in crop growing period will directly influence the crop irrigation demand results.

Simpler empirical methods will result in PET estimation with better spatial resolution than those more complicated methods. The PET values in the Northeast (such as Hetao area and Erdos area) and downstream of the Yellow River is relatively higher. It shows the PET is highly influenced by humidity or temperature in the Yellow River basin. In highly heterogeneous areas like the Yellow River basin, higher spatial resolution is very valuable. Further analysis on spatial characters in GIS system is needed in future studies.

\section{(3) Limitations}

Firstly, there are some limitations due to the lack of dataset in this study. Though Penman-Monteith method was widely recognized as a standard PET estimation method, the PET estimation by this method may not necessarily represent the real PET in the Yellow River basin. It would be ideal if the actual 
monitoring PET dataset can be used for calibration. Also, when calculating PET in the Yellow River basin, the proxy air pressure dataset derived from elevation was used which will cause bias. Only 10 stations in the year of 2002 were selected to represent the 4 climate areas in the Yellow River basin. Calibration with more stations will produce more reliable results. Further study is needed with more sufficient datasets in order to chieve more reliable calibration results. Secondly, when used in RCMs with future climate change scenarios, calibrated results may become invalid if future climate condition varies too much from current climate one. Therefore before applying these empirical methods, it is always advisable to be cautious of the abnormality degree of climate change.

ACKNOWLEDGEMENT: The authors would like to thank Professor Shi Peijun for his suggestions. Financial assistance for this work was provided by the CREST of Japan Science and Technology Corporation under the project "Sustainable development and management for water resources in the Yellow River basin". I am also grateful to the referees who provided valuabal suggestions that led to an improved manuscript.

\section{APPENDIX A Penman-Monteith Method}

Penman-Monteith method used in this study is often referenced as FAO-56 Penman-Monteith method. It is a grass reference equation ${ }^{1)}$ as follows:

$$
E T=\frac{0.408 \Delta\left(R_{n}-G\right)+\gamma \frac{900}{T_{a}+273} u_{2}\left(e_{s}-e_{a}\right)}{\Delta+\gamma\left(1+0.34 u_{2}\right)}
$$

where

$E T=$ reference evapotranspiration $\left(m m\right.$ day $\left.^{-1}\right)$,

$R_{n}=$ net radiation $\left(M J m^{-2} d a y^{-I}\right)$,

$G=$ soil heat flux density $(M J m-2$ day-1),

$T=$ air temperature at $2 \mathrm{~m}$ height $\left({ }^{\circ} \mathrm{C}\right)$,

$u_{2}=$ wind speed at $2 \mathrm{~m}$ height $\left(\mathrm{ms}^{-l}\right)$,

$e_{s}=$ saturation vapour pressure $(\mathrm{kPa})$,

$e_{a}=$ actual vapour pressure $(k P a)$,

$e_{s}-e_{a}=$ saturation vapour pressure deficit $(k P a)$,

$\Delta=$ slope vapour pressure curve $\left(k P a{ }^{\circ} \mathrm{C}-1\right)$,

$\gamma=$ psychrometric constant $\left(\mathrm{kPa}{ }^{\circ} \mathrm{C}-\mathrm{l}\right)$.

Latent heat of vaporization $(\lambda)$

$$
\lambda=2.501-\left(2.361 \times 10^{-3}\right) T_{a}
$$

where $\lambda=$ latent heat of vaporization $\left(M J \mathrm{~kg}^{-1}\right)$,

$$
T_{a}=\text { mean air temperature }\left({ }^{\circ} \mathrm{C}\right)
$$

\section{Atmospheric pressure $(P)$}

$$
P=101.3\left(\frac{293-0.0065 z}{293}\right)^{5.26}
$$

where $P=$ atmospheric pressure $(\mathrm{kPa})$,

$$
z=\text { elevation above sea level }(m) \text {. }
$$

\section{Saturation vapour pressure $\left(e_{s}\right)$}

$$
e_{s}=0.6108 \exp \left(\frac{17.27 T_{a}}{T_{a}+237.3}\right)
$$

where $e_{a}=$ actual vapour pressure function $(\mathrm{kPa})$,

$T_{a}=$ mean air temperature $\left({ }^{\circ} \mathrm{C}\right)$.

Actual vapour pressure $\left(\boldsymbol{e}_{a}\right)$

$$
e_{a}=\frac{R H_{\text {mean }}}{100} \frac{e_{0}\left(T_{\max }\right)+e_{0}\left(T_{\min }\right)}{2}
$$

where

$e_{a}=$ actual vapour pressure function $(\mathrm{kPa})$,

$e_{0}\left(T_{\max }\right)$ and $e_{0}\left(T_{\min }\right)$ follows equation 4.

Slope vapour pressure curve ( $\Delta)$

$$
\Delta=\frac{4098 e_{s}\left(T_{a}\right)}{\left(T_{a}+237.3\right)^{2}}=\frac{2504 \exp \left(\frac{17.27 T_{a}}{T_{a}+237.3}\right)}{\left(T_{a}+237.3\right)^{2}}
$$

where

$\Delta=$ slope vapour pressure curve $\left(\mathrm{kPaC} \mathrm{C}^{-1}\right)$, $T_{a}=$ mean air temperature $\left({ }^{\circ} \mathrm{C}\right)$.

\section{Psychrometric constant $(\gamma)$}

$$
\gamma=\frac{C_{p} P}{\varepsilon \lambda} \times 10^{3}=0.00163 \frac{P}{\lambda}=0.665 \times 10^{-3} P
$$

where

$\gamma=$ psychrometric constant $\left(\mathrm{kPa}^{\circ} \mathrm{C}-\mathrm{l}\right)$,

$p=$ atmospheric pressure $(k P a)$,

$\lambda=$ latent heat of vaporization, $2.45(M J \mathrm{~kg}-\mathrm{l})$,

$C_{p}=$ specific heat at constant pressure $(1.013 * 10-3$

$M J k g-1{ }^{\circ} \mathrm{C}^{-1}$ ),

$\varepsilon=$ ratio molecular weight of water vapour/dry air (0.622).

\section{Extraterrestrial radiation for daily periods $\left(R_{a}\right)$}

$$
R a=\frac{24(60)}{\pi} G_{s c} \operatorname{Dr}\left[\omega_{s} \sin (\varphi)+\cos (\varphi) \cos (\delta) \sin \left(\omega_{s}\right)\right]
$$

where

$$
\begin{aligned}
& R_{a}=\text { extraterrestrial radiation }\left(M J \mathrm{~m}^{-2} \mathrm{day}^{-1}\right), \\
& G_{s c}=\text { solar constant }=0.0820 \mathrm{MJ} \mathrm{m}^{-2} \mathrm{~min}^{-1}, \\
& D_{r}=\text { inverse relative distance Earth-Sun, } \\
& \omega_{\mathrm{s}}=\text { sunset hour angle }(\mathrm{rad}), \\
& \varphi=\text { latitude }(\mathrm{rad}),
\end{aligned}
$$


$\delta=$ solar decimation $(\mathrm{rad})$.

\section{Solar radiation $\left(R_{s}\right)$}

$$
R_{s}=\left(a_{s}+b_{s} \frac{n}{N}\right) R_{a}
$$

where

$R_{s}=$ solar radiation, $\left(M J m^{-2} d a y^{-1}\right)$,

$n=$ actual duration of sunshine (hour),

$N=$ max possible duration of sunshine (hour)

$a_{s}=$ regression constant, representing the solar radiation reaching the earth when $n=0$,

$a_{s}+b_{s}=$ representing the solar radiation reaching the earth when $n=1$. Values of 0.25 and 0.75 are used for $a_{s}$ and $b_{s}$ in this study.

\section{Short wave radiation on a clear-sky day $\left(R_{s 0}\right)$}

$$
R_{s 0}=\left(0.75+2 \times 10^{-5} z\right) R_{a}
$$

where

$R_{s 0}=$ clear-sky short wave radiation $\left(M J m^{-2} d^{I}\right)$,

$Z=$ elevation $(m)$,

$R_{a}=$ extraterrestrial radiation $\left(M J m^{-2} d^{-1}\right)$.

\section{Net solar or net short-wave radiation $\left(R_{n s}\right)$}

$$
R_{n s}=(1-\alpha) R_{s}
$$

where

$R_{n s}=$ net shortwave radiation $(M J m-2$ day- $)$,

$\alpha=$ albedo $(0.23$ for reference crop),

$R s=$ the incoming solar radiation $(M J m-2 d a y-1)$.

\section{Net long wave radiation $\left(R_{n l}\right)$}

$R_{n l}=\sigma \frac{\left[T^{4} \min , K+T^{4} \min , K\right]}{2}\left(0.34-0.14 \sqrt{e_{a}}\right)\left(1.35 \frac{R_{s}}{R_{s 0}}-0.35\right)$

where

$R_{n l}=$ net outgoing long wave radiation $\left(M J \mathrm{~m}^{-2}\right.$ day $\left.^{-1}\right)$,

$\sigma=$ Stefan-Boltzmann constant $\left(4.903 * 10^{-9} M J\right.$ $K^{-4} m^{-2}$ day $^{-1}$ )

$T_{\max , K}, T_{\min , K}=$ maximum and minimum absolute temperature during the 24-hour period,

$e_{a}=$ actual vapour pressure $(\mathrm{kPa})$,

$R_{s} / R_{s o}=$ relative short-wave radiation,

$R_{s}=$ solar radiation $\left(M J m^{-2}\right.$ day $\left.^{-1}\right)$,

$R_{s o}=$ calculated clear-sky radiation $\left(M J m^{-2} d a y^{-l}\right)$.

Net radiation $\left(\boldsymbol{R}_{n}\right)$

$$
R_{n}=R_{n s}-R_{n l}
$$

\section{Soil heat flux $(G)$}

$$
G=c_{s} \frac{T i-T_{i-1}}{\Delta t} \Delta z
$$

where

$G=$ soil heat flux $\left(M J m^{-2} d a y-1\right)$,

$c_{s}=$ soil heat capacity $\left(M J m^{-3}{ }^{\circ} \mathrm{C}-1\right)$, value of 0.14

is used in this study.

$T_{i}=$ soil temperature at time $\mathrm{i}\left({ }^{\circ} \mathrm{C}\right)$,

$T_{i-1}=$ soil temperature at time $\mathrm{i}-1\left({ }^{\circ} \mathrm{C}\right)$,

$\Delta_{t}=$ length of time interval (day),

$\Delta_{z}=$ effective soil depth $(m)$.

\section{REFERENCES}

1) Ryosuke Ozawa, Sigeu Ogawa, Fang Weihua, Hidefumi Imura.: Agricultural product and distribution water in the Yellow River basin in China, Proc. of $30^{\text {th }}$ Annual Meeting of Environmental Systems Research, 2002.

2) Dawen Yang, Chong Li, Musiake Katumi and Kusuda Tetsuya.: Variation of water resources of theYellow River basin in last century, Proceedings of the first int. conf. on hydrology and water resources in Asia Pacific Region, 2003.

3) Liu Changming, He Xiwu, et al.: Water problem strategy for China's 21 st century, Science Press, Beijing, China, 2001.

4) Allen, R. G., Pereira, L. S., Raes, D. and Smith, M.: Crop evapotranspiration: Guidelines for computing crop water requirements, FAO Irrigation and Drainage Paper 56, FAO, 1998.

5) Chen Yunhao, Li xiaobing, Jing Guifei, and Shi Peijun.: An estimation model for daily regional evapotranspiration, Int. J. Remote Sensing, Vol.24, No. 1, 2003.

6) IPCC.: Climate Change 2001: The Scientific Basis, Cambridge University Press, 2001.

7) Singh,V.P. and Xu, C.-Y.: Evaluation and Generalization of 13 Equations for Determining Free Water Evaporation, Hydrol. Processes Vol.11,1997.

8) Xu, C.-Y. and Singh,V. P.: Evaluation and generalization of radiation-based methods for calculating evaporation, Hydrolog. Processes, Vol.15, 2001.

9) Thornthwaite,C.W.: An approach toward a rational classification of climate, Geographic Review 38, 55-94, 1948.

10) Blaney, H. F. and Criddle, W. D.: Determining water requirements in irrigated area from climatological irrigation data, US Department of Agriculture, Soil Conservation Service, Technical Paper. No. 96, 1950.

11) Hargreaves, G. H. and Samni, Z. A.: Reference crop evapotranspiration from temperature, Transaction of the ASAE, 1985.

12) Makkink, G. F.: 1957 , Testing the penman formula by means of lysimeters, Journal of Institution Water Engineers 11, 1957.

13) Priestley, C. H. B. and Taylor, R. J.: On the assessment of the surface heat flux and evaporation using large-scale parameters, Monthly Weather Review 100, 1972.

14) Penman, H.L.: Natural evaporation from open water, bare soil and grass. Proc., Royal Soc., London, 1948

15) L., and Mitasova, H.: General variational approach to the interpolation problem, Comput. Math. Applic. Vol. 16. No. 12. pp. $983-992,1988$. 


\title{
黄河流域における経験式を用いたポテンシャル蒸発散量推計方法について
}

\author{
方 偉華・井村 秀文
}

本研究は, 黄河流域におけるポテンシャル蒸発散量(PET)の推計を行うものである. ポテンシャル蒸発散 量の推計に影響を及ぼす主な因子は，適用性や気象パラメータの入手可能性である. 第一に, Penman-Monteithの推計方法を基準として，6の経験的なポテンシャル蒸発散量の推計方法を比較及びキャ リブレーションした. 6の経験的な推計方法は, Thornthwaite, Blaney-Criddle, Hargreaves, Priestley-Taylor, Makkink, Penmanである. 2002年における10ケ所の気象観測所での完全な日常の気象データが，比較及びキ ヤリブレーションに用いられた. キャリブレーションの結果、Makkinkの推計手法が最適であるという結 果を得た。第二に、黄河流域におけるポテンシャル蒸発散量が，190地域からの温度と日射時間から, キャ リブレーションしたMakkinkの推計方法により推計された. 